\title{
Musculoskeletal disorders in manual therapistis
}

\author{
Kátia Karina Monte Silva', Angélica da Silva Tenório', Marcelo Renato Guerino', Mafra Raiele Torres Oliveira², \\ Mannaly Braga de Mendonça ${ }^{3}$, Maria de Fátima Alcântara Barros ${ }^{4}$, Antônio Geraldo Cidrão de Carvalho4, \\ Ana Paula de Lima Ferreira5 ${ }^{5}$ Maria das Graças Rodrigues de Araújo ${ }^{6}$
}

\begin{abstract}
Introduction: Musculoskeletal Disorders (MDEs) are inflammatories and degenerative diseases that are a public health problem. In recent years among registered occupational diseases worldwide are the most prevalent, affecting the quality of life of individuals. Objective: To investigate the occurrence and characteristics of MDEs on physiotherapists who use manual therapy techniques in Recife-Pernambuco. Method: 34 therapists of both genders responded standardized questionnaire (demographic characteristics and complaints of musculoskeletal diseases) in regular time and in the workplace (public and private health services). Data were analyzed by chi-square test $\left(\left(\chi^{2}\right)\right.$, a significance level of $95 \%(p<0.05)$, BioEstat program version 3.0. Results: It was found that $88.2 \%$ of the sample refers to any type of MDEs, but the spine (76.6\%) and upper (70.6\%) were most often affected, especially wrists and hands (56,7\% ).There were no significant correlations between MDEs and gender of the therapist and not with the playing time (years) profession, however the occurrence of these disturbances was correlated to the age of the professional. There was a direct relationship between workload and the presence of DMEs. Conclusion: The results indicate that the manual therapists in the performance of intense activity partners have high percentages of involvement by musculoskeletal disorders, requiring preventive ergonomic measures.
\end{abstract}

Keywords: Musculoskeletal disorders, Manual therapy, Occupational injuries

\section{INTRODUCTION}

The Musculoskeletal Disorders (DMEs) are a set of inflammatories and degeneratives diseases that are a major public health problem, have been in recent years, among registered occupational diseases, the most prevalent in the world interfering on the quality of life of the people..$^{(1,2)}$

In Europe, in 2008, about 100 million workers suffer from musculoskeletal chronic pain in the upper limbs or neck, representing high work absenteeism with an estimated loss of 4.1 million days. ${ }^{(3)}$

In the USA, in 2012, the teams accounted for $34 \%$ of all diseases and disorders of nonfatal occupational health, taking them in spine disorders representing $42 \%$ of all cases, but the most severe cases were in shoulder. ${ }^{(4)}$

In Brazil, 2013, the total number of occupational accidents registered with Work Accident Communication (WAC) by the INSS, were granted 76,400 benefits of sick pay, which represents almost a third of the 304,000 departures accounted for $2.8 \%$ and the most frequent illnesses, according to the International Classification of Diseases (ICDs) were shoulder injuries (M75), with 20.2\%; synovitis and tenosynovitis (M65), with $14.2 \%$; and back pain (M54), with $7.7 \%$ : the range of highest incidence was $30-39$ years with $33.9 \%$ of all accidents recorded. ${ }^{(5)}$

The DMEs, also called osteo-muscular disorders are common among workers in the health area, which are mainly due to biomechanical factors such as repeatability of the same movement pattern. These professionals are often exposed to physical and mental overload during prolonged work hours which makes them susceptible to DMEs. ${ }^{(6.7)}$ Physical therapists are included in these risk groups, as reported by studies that have shown a high prevalence of these DMEs professionals. $(8,9,10,11,12)$

Routinely the physiotherapist carries out activities that overload the musculoskeletal system such as transfer-dependent patients, patient care during ambulation, manual resistance and lifting weights and equipment occurring mechanical pressure on certain parts of the body, static muscular work, shock and vibration. ${ }^{(13,14)}$

These professionals work in uncomfortable positions for long periods and periodically perform repetitive movements of the upper limbs, making them more likely to develop problems with this system. ${ }^{(14,15)}$ 
Despite the physiotherapist already it poses a risk group to develop DMEs, scholars ${ }^{(16.17)}$ showed that among those physiotherapists who performed techniques of manual therapy had a higher prevalence of these disorders.

Manual therapy comprises a set of techniques that the therapist uses mainly his hands as the main instrument to take care of the patient. ${ }^{(18-19)}$ Despite the benefits provided to patients who are treated with these techniques, these require the therapist great efforts in their musculoskeletal system, making it therefore more prone to DMEs. ${ }^{(20)}$

Some studies show that physical therapists are highly prevalent in osteo-muscular disorders ${ }^{(21,22,23)}$, however, few have investigated the prevalence of DMEs in therapists who routinely use manual therapy to treat their patients.

The objective of this study was to investigate the occurrence and characteristics of musculoskeletal disorders in physical therapists using technique manual therapy of the city of Recife-Pernambuco, as well as its relation to age, gender, working hours, area of operatiom and time performance of these professionals.

\section{METHOD}

This research is characterized as a descriptive cross-sectional study conducted from data from a study investigating the prevalence of musculoskeletal disorders in physical therapists in the city of Recife, Pernambuco. ${ }^{(24)}$

Data were collected through self-administered questionnaires given to physiotherapists, who signed a Consent and Informed $(\mathrm{Cl})$ agreeing to the study, which was approved by the Ethics Committee on Human Research of the Federal University of Pernambuco in $191 \backslash 2005$, according to Resolution 196/96 of the National Health Council of the Ministry of Health.

The questionnaires were delivered in regular time and in the workplace, public and private health services in the city of Recife-Pernambuco, and was asked to answer the questionnaires and returned within two weeks.

The questionnaire, adapted from Holder et $a^{(11)}$, consists of questions (semi-open and closed) on demographic characteristics (name, gender, marital status, address, place of birth, height, weight), professional activities (local, time and area of operation, routine use of manual techniques, workload) and complaints of musculoskeletal diseases (types of disorders, most affected region). On some items of the questionnaire was allowed the therapist to score more than one answer.

The sample consisted of 34 physical therapists, of both genders, aged 24 and 60 , who stated in the questionnaire apply manual therapy techniques routinely in your workday. Data were statistically analyzed using the chi-square test $\left(\chi^{2}\right)$, with significance level set at $95 \%(p<0.05)$ by BioEstat program version 3.0.

\section{RESULTS}

The Table 1 characterizes the sample according to sociodemographic variables, mainly, the study participants were female (79.4\%). Most of the sample (35.3\%) were located in the age group 31-40 years and the change in the age $24-60$ years.

In the place of performance of the therapists, the predominant hospital was with $67.6 \%$, with the latter clinics with $61.8 \%$; already, in the operating area it was observed that $79.4 \%$ work in trauma and orthopedics, $35.3 \%$ also in rheumatology and neurology and cardio-respiratory $17.6 \%$.

The Table 2 shows the results for the regions of incidence of the disorder or injury to the musculoskeletal system. In the

Table 1. Socio-demographic characterization of manual therapists with distribution of the population studied by location and professional area. Frequency corresponds to absolute number of therapists and\% $\mathrm{N}$ value for the sample size $(n=34)$.

\begin{tabular}{|c|c|c|}
\hline Variables & $\begin{array}{c}\text { Frequency } \\
n=34\end{array}$ & $\% \mathrm{~N}$ \\
\hline \multicolumn{3}{|l|}{ Genre } \\
\hline Female & 27 & 79.4 \\
\hline Male & 7 & 20.6 \\
\hline \multicolumn{3}{|l|}{ Age (years) } \\
\hline $24-30$ & 11 & 32.3 \\
\hline $31-40$ & 12 & 35.3 \\
\hline $41-50$ & 7 & 20.6 \\
\hline $51-60$ & 4 & 11.8 \\
\hline \multicolumn{3}{|l|}{ Practice site } \\
\hline Hospital & 23 & 67.6 \\
\hline Clinic & 21 & 61.8 \\
\hline Home Care & 14 & 41.2 \\
\hline Others & 1 & 2.9 \\
\hline \multicolumn{3}{|l|}{ Practice Area } \\
\hline Traumatology and Orthopaedics & 27 & 79.4 \\
\hline Rheumatology & 12 & 35.3 \\
\hline Neurology & 12 & 35.3 \\
\hline Cardiopulmonary & 6 & 17.6 \\
\hline Other & 3 & 8.8 \\
\hline
\end{tabular}

According to the data of Figure 1 there was the occurrence of musculoskeletal disorders (DMEs) in $88.2 \%$ of manual therapists active in the health services of the city of Recife.

Table 2. Body location of musculoskeletal disorders in manual therapies and the distribution of the population studied by location and professional area $(n=34)$. In these variables the therapist may mark more than one option.

\begin{tabular}{lcc}
\hline \multirow{2}{*}{ Location of the DMEs* } & \multicolumn{2}{c}{ Distribution Therapists Manuals $(\mathbf{n}=\mathbf{3 0})$} \\
\cline { 2 - 3 } & Frequency & N\% \\
\hline Cervical Spine & 18 & 60.0 \\
Dorsal Column & 11 & 36.7 \\
Lumbar Spine & 18 & 60.0 \\
Shoulders & 15 & 50.0 \\
Elbows & 04 & 13.3 \\
Wrists and Hands & 17 & 56.7 \\
Knees & 04 & 13.3 \\
Ankles and Feet & 05 & 16.7
\end{tabular}


region of the spine $60.0 \%$ of manual therapists presented DMEs at cervical region; $36.7 \%$ in dorsal and lumbar $60.0 \%$ and $76.6 \%$ of one or more segments; $24(70.6 \%)$ in the upper limbs, especially in the wrists and hands (56.7\%) and only $20.6 \%$ in the lower limbs.

The correlations between the presence of musculoskeletal disorders in manual therapists and professional performance time, age and the therapist's gender are presented in Table 3.

In Figure 2, we observed that the occurrence of DMEs increased progressively with increasing hours worked per

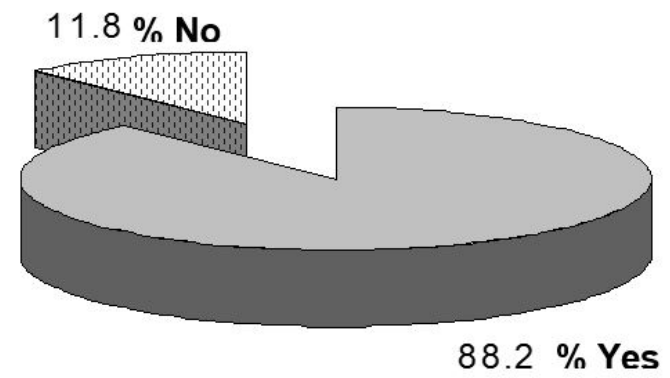

Figure 1. Occurrence of musculoskeletal disorders (DMEs) in manual therapies. Yes $=$ the presence of DMEs; No = no DMEs.

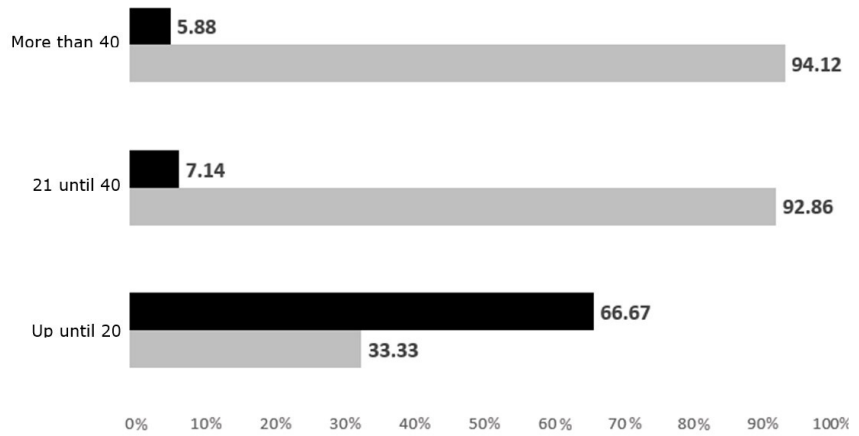

Figure 2. Occurrence of musculoskeletal disorder in manual therapies related to weekly working hours. Percent relative to the number of individuals in each time interval. Light bars: therapists with DMEs and dark bars: therapists without DMEs. week, with regard to the occurrence of musculoskeletal disorders with this variable.

\section{DISCUSSION}

Study ${ }^{(25)}$ shows that the work of physiotherapists in the practice of manual therapy techniques increases the likelihood of developing musculoskeletal disorder in relation to physical therapists who do not practice this type of therapy, which confirms the high occurrence of DMEs of therapists manuals of this study.

Manual therapy techniques require much of the musculoskeletal system physiotherapist due to routine practice of repetitive movements and maintaining postures for prolonged periods. ${ }^{26,27)}$ Moreover, equipment, furniture and environments clinics and hospitals usually do not respect ergonomic principles necessary for the development of techniques, thus facilitating the propensity of the manual therapist osteo-muscular disorders. ${ }^{8,22,28,29)}$ Emergency situations that overwhelm the individual journey often extensive, doubled and shifts, and monitoring direct ill health and suffering of patients, also cause the therapist in addition to physical exhaustion, psychological stress, providing thus an increased risk of developing disorders in the musculoskeletal systems of these professionals. ${ }^{(8,31,32)}$

The high occurrence of disorders in the spine observed in manual therapists from Recife-Pernambuco may be due to the frequency, the application of technical manuals, activities such as bending forward and trunk rotation, often with load-bearing, causing, as well, changes in body biomechanics and triggering muscle fatigue and probable osteo-muscular injuries corroborating work done with the physios target audience. (31,32)

Most of the techniques used in manual therapy, such as soft tissue mobilization, also expose the upper limbs risk factors associated with musculoskeletal and neurovascular disorders. ${ }^{(33)}$ This was confirmed in this study with high occurrence of disorders in the upper limbs, particularly the wrists and hands. These findings suggest that manual therapy

Table 3. Distribution of manual therapists with DMEs. $(n=30)$ according to gender, age and time of practice.

\begin{tabular}{|c|c|c|c|c|c|}
\hline Variables & Score/DMEs (n) & & $\%$ & $\mathbf{x}^{2}$ & p \\
\hline Genre & & & & 2.40 & 0.121 \\
\hline Female & 25 & & 92.59 & & \\
\hline Male & 5 & & 71.43 & & \\
\hline \multirow{4}{*}{ Age (years) } & & & & 14.618 & 0.0001 \\
\hline & $\leq 30$ & 8 & 72.73 & & \\
\hline & $>30$ & 22 & 95.65 & & \\
\hline & & & & 0.266 & 0.606 \\
\hline \multirow{2}{*}{ Professional performance (years) } & $<8$ & 11 & 84.62 & & \\
\hline & $\geq 8$ & 19 & 90.48 & & \\
\hline
\end{tabular}

$\mathrm{X}^{2}=$ Chi-square test; $\mathrm{p}<0,05$ (significance level). $\%=$ percentage on the number of individuals per score. 
techniques are a source of stress to the musculoskeletal system of the upper limbs.

However, occurrences of DMEs presented is directly proportional to the workload of the therapist, corroborating other studies. ${ }^{(9,33)}$ Excessive hours of weekly work of manual therapists is reflected as physical overload, exposing the professional to health risks.

Kuwait developed work (17) found no correlation of musculoskeletal disorders with the gender of the therapist. In the present study, the number of respondents manual therapists females was higher than males, indicating that women are more susceptible to diseases of the DMEs. Other studies have shown that women are more prone to DMEs than men. ${ }^{(9,34)}$ This divergence of results may be due to the difference between countries where were carried out the research and who generally have levels of development of the profession status and different epidemiological and psychosocial factors, and this may contribute to the risk factors distinct from therapists. ${ }^{(17)}$

Several studies show that age and time of operation are risk factors prevalent in the development of DMEs for physiotherapists and for most authors ${ }^{(32)}$, the first episode usually occurs before age 30 , and the older physiotherapists have lower prevalence of these disorders because they are the ones that develop more strategies to suit the physical demands of the job. ${ }^{(30,34)}$

This finding was not confirmed by this study, as increasing age increased the risk of manual therapist to develop the disorder, which may show the high body burden index for manual therapists who remain in these activities for several years. Scholars have linked the involvement of young professionals by musculoskeletal disorders to inexperience coupled with the will to overcome, inadequate environments, and also add to all these factors the lack of professional training regarding the knowledge ergonomic, biomechanical and postural. ${ }^{(35)}$ Regarding the operating time, no correlation was observed in the occurrence of DMEs in manual therapists in the city of Recife. This result was similar to other studies ${ }^{(37,38)}$ which showed negative correlation between incidence of back pain and number of years of physiotherapist experience. Previous studies in the literature ${ }^{(12,34)}$ showed that despite the physical therapists have knowledge of the pathological mechanisms of injuries and forms of treatment do not apply such knowledge when they themselves are affected, they continue working even in the presence of pain or discomfort. This is well evidenced by scholars ${ }^{\left({ }^{9}\right)}$ who report the percentage of $6.5 \%$ of respondents commented have changed their manual therapy activities due to pain in the hands and fingers.

Changes like reducing patient time, ergonomic measures to further develop the technical and other preventive measures are required for manual therapists do not develop musculoskeletal disorders and can continue assisting their patients.

\section{CONCLUSION}

This study shows that therapists manuals play intense professional activities in the city of Recife-Pernambuco have high percentages of involvement by musculoskeletal disorders, especially in the spine and upper limbs. The sharp occurrence of these disturbances, in this profession, seems to be related to the physical and mental burden which these professionals are exposed in the workplace. Is, therefore, necessary to develop preventive measures to reduce the disturbances in the musculoskeletal system in the practice of manual therapy.

\section{AUTHOR'S CONTRIBUTIONS:}

KKMS AST APLF: Collect the data, conceived and designed the experiments MRTO MBM: Review the literature, wrote and corrected the article MFAB AGCC MRG: Analysed the data

MGRA: Guided the work, conceived and designed the experiments

\section{CONFLICTS OF INTEREST:}

There are no conflicts of interest.

\section{AUTHOR DETAILS}

${ }^{1}$ Department of Physiotherapy, Universidade Federal de Pernambuco, Recife (PE), Brazil

${ }^{2}$ Instituto de Medicina Integral Professor Fernando Figueira - IMIP, Recife (PE), Brazil.

${ }^{3}$ Universidade Federal de Pernambuco, Recife (PE), Brazil.

${ }^{4}$ Department of Physiotherapy, Universidade Federal da Paraiba, João Pessoa (PB), Brazil.

${ }^{5}$ Department of Physiotherapy, Laboratory of Kinesiotherapy and Manual Therapeutic Resources, Universidade Federal de Pernambuco, Recife (PE), Brazil.

\section{REFERENCES}

1. Punnett L, Wegman DH. Work-related musculoskeletal disorders: the epidemiologic evidence and the debate. Jornal of Electromyography and Kinesiology. 2004;14(1):13-23.

2. Martarello NA, Benatti MCC. Qualidade de vida e sintomas osteomusculares emtrabalhadores de higiene e limpeza hospitalar. Rev. Esc. Enferm. USP. 2009; 43(2).

3. Buckle P. Ergonomics and musculoskeletal disorders: overview. Occupational Medicine. 2005;55:164 -67.

4. Bureau of labor statistics/U.S. department of labor: Nonfatal occupational injuries and illnesses requiring days away fromwork. 2011. Disponível em: <http://www.bls.gov/news. release/pdf/osh2.pdf>. Acesso em: 04 de maio de 2014.

5. Quantidade de AT registrados por motivo, segundo os 50 códigos da Classificação Internacional de Doenças, mais incidentes em 2011. Disponível em: >http://www.protecao.com.br/materias/anuario_ brasileiro_de_p_r_o_t_e_c_a_o_2013/brasil/J9y4Jj>. Acesso em: 20 de abril de 2014.

6. Galinsky T, Waters T, Malit B. Overexertion injuries home health care workers and the need for ergonomics [abstract]. Home health care services quarter. 2001;20(3):57-73.

7. Ribeiro NA, Fernandes RCP, Solla DJF, Santos Júnior AC, Sena Júnior AS. Prevalência de distúrbios osteomusculares relacionados ao trabalho em profissionais de enfermagem. Rev Bras Epidemio. 2012;15(2): 429-38.

8. Gisbert MFS, Los Fayos EJG, Montesin MDH. Burnout en fisioterapeutas españoles. Psicothema. 2008;20(3):361-368.

9. Cromie JE, Robertson VJ, Best MO. Work-related musculoskeletal disorders on physical therapists: prevalence, severity, risks, and responses [abstract]. Physical Therapy. 2000;80(4):336-351. 
10. Campo M, Weiser S, Koenig KL, Nordin M. Work-Related Musculoskeletal Disorders in Physical Therapists: A Prospective Cohort Study With 1-Year Follow-up. Phys. Ther. 2008;88:608-619.

11. Holder, N. L., Clark, H. A., DiBlasio, J. M., Hughes, C. L., Scherpf, J. W., Harding, L., \& Shepard, K. F. (1999). Cause, prevalence, and response to occupational musculoskeletal injuries reported by physical therapists and physical therapist assistants. Physical therapy, 79(7), 642-652.

12. Leanne P, Steven M. Work related musculoskeletal disorders amongst Therapists in hysically demanding roles: Qualitative analysis of risk factors and strategies. BMC Musculoskeletal Disorders. 2011;12:24.

13. Pastre EC, Filho GC, Pastre CM, Padovani CR, Almeida JS, Junior JM. Queixas osteomusculares relacionadas ao trabalho relatadas por mulheres de centro de ressocialização. Cad. Saúde Pública. 2007;23: 11.

14. King P, Weddleston D, Darragh AR. Work-Related Musculoskeletal Disorders and Injuries: Differences Among Older and Younger Occupational and Physical Therapists. J Occup Rehabil. 2009;19:274-283.

15. Adegoke B, Akodu A, Oyeyemi A. Work-related musculoskeletal disorders among Nigerian Physiotherapists. BMC Musculoskeletal Disorders. 2008,9(1):11.

16. Sin HC, Jin GH, Taesung K, Jooyeon K, Heesoo K, Ju SL, et al. Work-related musculoskeletal Disorders among Korean Physical Therapists. J. Phys. Ther. Sci. 2013, 25:55-59.

17. Alrowayeh HN, Alshatti TA, Aljadi SH, Fares M, Alshamire MM, Alwazan SA. Prevalence, characteristics, and impacts of work-related musculoskeletal disorders: a survey among physical therapists in the State of Kuwait. BMC Musculoskelet Disord. 2010;11:2-11.

18. Smith AR Jr. Manual Therapy: The Historical, Current, and Future Role in the Treatment of Pain. The Scientific World Journal. 2007;2(7):109-20.

19. Vernon $\mathrm{H}$, Humphreys BK. Manual Therapy for neck pain: an overview of randomized clinical trials and systematic reviews. Eura Medicophys. 2007;43(1):91-118.

20. West DJ, Gardner D. Occupational injuries of physiotherapists in North and Central Queensland. Aust J Physiother. 2001;47(3):179-86.

21. Shehab D, Al-Jarallah K, Moussa MA, Adham N. Prevalence of low back pain among physical therapists in Kuwait. Medical Principles and Practice. 2003;12(4):224-30.

22. Siqueira GR, Cahú FGM, Vieira RAG. Occurrence of low back pain in physical therapists from the city of Recife, Pernambuco, Brazil. Rev Bras Fisioter. 2008;12(3):222-7.

23. Almeida FRT, Brandão BB, Rocha CAQC. Índice de lesões e afecções musculoesqueléticas relacionadas aos profissionais da área de fisioterapia da cidade de Muriaé, MG. Revista Científica Faminas. 2008; 4( 3): 53-63.

24. De Araújo, M. D. G. R., \& Manuais, R. T. (2014). Estudo dos distúrbios musculoesqueléticos em fisioterapeutas: correlação com a rotina do trabalho. MTP\&RehabJournal 2014, 12:567-582.
25. D’Ávila LS, Sousa GAF, Sampaio RF. Prevalência de Desordens Musculoesqueléticas Relacionadas ao Trabalho em Fisioterapeutas da Rede Hospitalar SUS-BH. Revista Brasileira de Fisioterapia. 2005;9(2):219225.

26. Paula EB, Guimarães G. Caracterização do quadro álgico dos profissionais: professores, cirurgiões, dentistas e fisioterapeutas. Revista CEPPG. 2009;12(21):114-126.

27. Paula EB, Guimarães G. Caracterização do quadro álgico dos profissionais: professores, cirurgiões, dentistas e fisioterapeutas. Revista CEPPG. 2009;12(21):114-126.

28. Nyland LJ, Grimmer KA. Is undergraduate physiotherapy study a risk factor for low back pain? A prevalence study of LBP in physiotherapy students. BMC Musculoskeletal Disorders. 2003;4:22.

29. Cromie JE, Robertson VJ, Best MO. Occupational health in physiotherapy: General health and reproductive outcomes. Australian Journal of Physiotherapy. 2002;48:287-294.

30. Moreira ACC, Coutinho CCC, Lucena NMG. Study of the Relation of Workrelated Musculoskeletal Disorders (MSDS) and Fibromyalgia: a Review of Literature. Revista Brasileira de Ciências da Saúde. 2010;14(2):101-111.

31. Pivetta $A D$, Jacques MA, Agne JE, Lopes LF. Prevalência de distúrbios osteomusculares relacionados ao trabalho em fisioterapeutas. Revista Digital: Buenos Aires. 2005;10(80).

32. Renner JS. Prevenção de distúrbios osteomusculares relacionados ao trabalho, In: Boletim Saúde. Porto Alegre. 2005;19(1):73-80.

33. Trelha CS, Gutierrez PR, Matsuo T. Prevalência de sintomas musculoesqueléticos em fisioterapeutas da cidade de Londrina. Rev Fisioter Univ São Paulo. 2004;11(1):15-23.

34. Lima, J. P. D., Sousa, A. P. D., Santos, E. V. D. L., Bezerra, A. L. D., \& Sousa, M. N. A. D. (2015). Prevalência de Distúrbios Osteomioarticulares e Algias em Fisioterapeutas. Revista de Saúde Pública de Santa Catarina,8(3), 98108.

35. Bork, B. E., Cook, T. M., Rosecrance, J. C., Engelhardt, K. A., Thomason, M. E. J., Wauford, I. J., \& Worley, R. K. (1996). Work-related musculoskeletal disorders among physical therapists. Physical therapy,76(8), 827-835.

36. Silva C S, Silva MAG. Lombalgia em fisioterapeutas e estudantes de fisioterapia: um estudo sobre a distribuição da freqüência. Revista fisioterapia Brasil, São Paulo. 2005;6(5).

37. Ciarlini IA, Monteiro PP, Braga ROM, Moura DS. Lesões por esforços repetitivos em fisioterapeutas. Revista brasileira em promoção da saúde, Fortaleza. 2004;18(1):1116.

38. Arantes AS, Nunes APRO. Prevalência de lombalgia nos fisioterapeutas atuantes na cidade de FormigaMG. Revista Brasileira em Promoção da Saúde. 2009;4(1). 